\title{
Determination of Ideal Broth Formulations Needed to Prepare Hydrous Cerium Oxide Microspheres via the Internal Gelation Process
}

\section{December 2008}

\author{
J. L. Collins
}

Anthony Chi

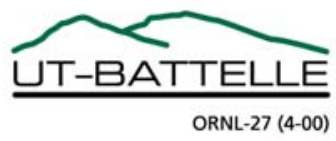




\section{DOCUMENT AVAILABILITY}

Reports produced after January 1, 1996, are generally available free via the U.S. Department of Energy (DOE) Information Bridge:

Web site: http://www.osti.gov/bridge

Reports produced before January 1, 1996, may be purchased by members of the public from the following source:

National Technical Information Service

5285 Port Royal Road

Springfield, VA 22161

Telephone: 703-605-6000 (1-800-553-6847)

TDD: 703-487-4639

Fax: 703-605-6900

E-mail: info@ntis.fedworld.gov

Web site: http://www.ntis.gov/support/ordernowabout.htm

Reports are available to DOE employees, DOE contractors, Energy Technology Data Exchange (ETDE) representatives, and International Nuclear Information System (INIS) representatives from the following source:

Office of Scientific and Technical Information

P.O. Box 62

Oak Ridge, TN 37831

Telephone: 865-576-8401

Fax: 865-576-5728

E-mail: reports@adonis.osti.gov

Web site: http://www.osti.gov/contact.html

This report was prepared as an account of work sponsored by an agency of the United States Government. Neither the United States government nor any agency thereof, nor any of their employees, makes any warranty, express or implied, or assumes any legal liability or responsibility for the accuracy, completeness, or usefulness of any information, apparatus, product, or process disclosed, or represents that its use would not infringe privately owned rights. Reference herein to any specific commercial product, process, or service by trade name, trademark, manufacturer, or otherwise, does not necessarily constitute or imply its endorsement, recommendation, or favoring by the United States Government or any agency thereof. The views and opinions of authors expressed herein do not necessarily state or reflect those of the United States Government or any agency thereof. 
Nuclear Science and Technology Division

\title{
DETERMINATION OF IDEAL BROTH FORMULATIONS NEEDED TO PREPARE HYDROUS CERIUM OXIDE MICROSPHERES VIA THE INTERNAL GELATION PROCESS
}

\author{
J. L. Collins \\ Anthony $\mathrm{Chi}^{*}$
}

Date Published: December 2008

\author{
Prepared by \\ OAK RIDGE NATIONAL LABORATORY \\ P.O. Box 2008 \\ Oak Ridge, Tennessee 37831-6283 \\ managed by \\ UT-BATTELLE, LLC \\ for the \\ U.S. DEPARTMENT OF ENERGY \\ under contract DE-AC05-00OR22725
}

\footnotetext{
${ }^{*}$ Former Beloit College student assigned to the Nuclear Science and Technology Division at ORNL through a grant appointment for Oak Ridge Associated Universities.
} 



\section{CONTENTS}

Page

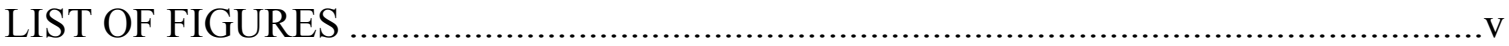

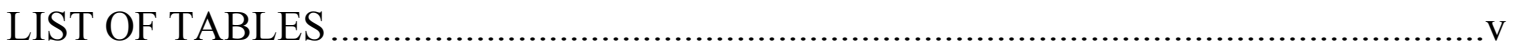

ABSTRACT .................................................................................................... vii

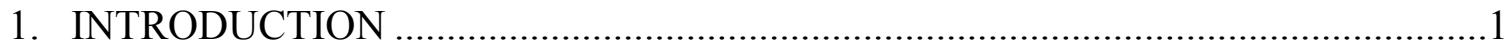

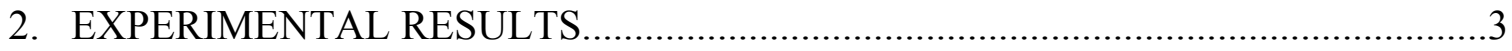

3. EXAMPLE OF ONE OF THE LAB-SCALE HYDROUS CERIUM OXIDE MICROSPHERE PREPARATIONS .......................................................10

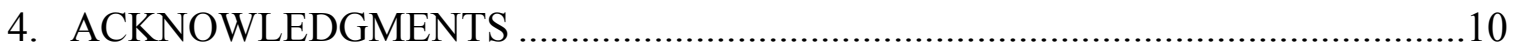

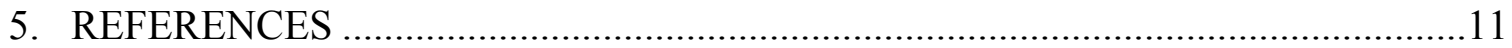

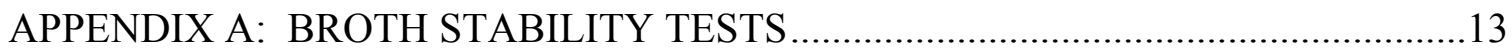

APPENDIX B: GEL TESTS IN GLASS CENTRIFUGE TUBES ..................................15

APPENDIX C: GRAVIMETRIC ANALYSIS PROCDRURE ………………..............17 



\section{LIST OF FIGURES}

Figure

Page

1 Gelation time as function of HMTA/ $\mathrm{Ce}^{4+}$ mole ratio for $\mathrm{Ce}^{4+}$ broths at $90,80,70$, and $60^{\circ} \mathrm{C}$ with a $\mathrm{OH}^{-} / \mathrm{Ce}^{4+}$ mole ratio of 0.00

2 Gelation time as function of $\mathrm{HMTA} / \mathrm{Ce}^{4+}$ mole ratio for $\mathrm{Ce}^{4+}$ broths at $90,80,70$, and $60^{\circ} \mathrm{C}$ with a $\mathrm{OH}^{-} / \mathrm{Ce}^{4+}$ mole ratio of 0.25

3 Gelation time as function of HMTA/ $\mathrm{Ce}^{4+}$ mole ratio for $\mathrm{Ce}^{4+}$ broths at $90,80,70$, and $60^{\circ} \mathrm{C}$ with a $\mathrm{OH}^{-} / \mathrm{Ce}^{4+}$ mole ratio of 0.50

4 Gelation time as function of HMTA/ $\mathrm{Ce}^{4+}$ mole ratio for $\mathrm{Ce}^{4+}$ broths

at $90,80,70$, and $60^{\circ} \mathrm{C}$ with a $\mathrm{OH}^{-} / \mathrm{Ce}^{4+}$ mole ratio of 1.00

5 Gelation time as function of $\mathrm{HMTA} / \mathrm{Ce}^{4+}$ mole ratio for $\mathrm{Ce}^{4+}$ broths with four different $\mathrm{OH}^{-} / \mathrm{Ce}^{4+}$ mole ratios at a gel-forming temperature of $60^{\circ} \mathrm{C}$

6 Gelation time as function of $\mathrm{HMTA} / \mathrm{Ce}^{4+}$ mole ratio for $\mathrm{Ce}^{4+}$ broths with four different $\mathrm{OH}^{-} / \mathrm{Ce}^{4+}$ mole ratios at a gel-forming temperature of $70^{\circ} \mathrm{C}$

7 Gelation time as function of $\mathrm{HMTA} / \mathrm{Ce}^{4+}$ mole ratio for $\mathrm{Ce}^{4+}$ broths with four different $\mathrm{OH}^{-} / \mathrm{Ce}^{4+}$ mole ratios at a gel-forming temperature of $80^{\circ} \mathrm{C}$

8 Gelation time as function of HMTA/ $\mathrm{Ce}^{4+}$ mole ratio for $\mathrm{Ce}^{4+}$ broths with four different $\mathrm{OH}^{-} / \mathrm{Ce}^{4+}$ mole ratios at a gel-forming temperature of $90^{\circ} \mathrm{C}$

\section{LIST OF TABLES}

\section{Table}

1 Recommended broths as a function of temperature of preparing hydrous cerium oxide gel spheres by the internal gelation process. 



\begin{abstract}
A simple test tube methodology was used to determine optimum process parameters for preparing hydrous cerium oxide microspheres via the internal gelation process. ${ }^{1}$ Broth formulations of cerium ammonium nitrate $\left[\left(\mathrm{NH}_{4}\right)_{2} \mathrm{Ce}\left(\mathrm{NO}_{3}\right)_{6}\right]$, hexamethylenetetramine, and urea were found that can be used to prepare hydrous cerium oxide gel spheres in the temperature range of 60 to $90^{\circ} \mathrm{C}$. A few gel-forming runs were made in which microspheres were prepared with some of these formulations to be able to equate the testtube gelation times to actual gelation times. These preparations confirmed that the test-tube methodology is reliable for determining the ideal broth formulations.
\end{abstract}





\section{INTRODUCTION}

The internal gelation process is one of the sol-gel processes developed for the preparation of microspheres of hydrous metal oxides in which chilled clear broth droplets containing the salt of the metal, hexamethylenetetramine (HMTA), and urea are heated, causing homogenous gelation and solidification of the droplets. ${ }^{1-15}$ After washing, the gel spheres can be air dried for use as engineered ion-exchange materials ${ }^{8-12}$ or, depending upon the metal, dried, calcined, and sintered to ceramic microspheres for use as nuclear fuel, ${ }^{2-7}$ catalysts, ${ }^{8-12}$ getters, ${ }^{8-11}$ or dielectrics. ${ }^{13-15}$ A previously reported test-tube methodology, ${ }^{1}$ which was employed to determine the optimum process parameters for preparing hydrous metal oxide microspheres, was also used in this study to determine the optimum process parameters for preparing hydrous cerium oxide microspheres. The testing procedures are described in Appendixes A and B. The key to being able to prepare hydrous cerium oxide gel spheres by internal gelation depended upon finding a cerium salt that would precipitate or gel at a $\mathrm{pH}<7$ in a nitrate solution. In solution, HMTA acts as a buffer that keeps the $\mathrm{pH}<7$. The $\mathrm{pH}$ values of precipitation of $\mathrm{Ce}^{3+}$ and $\mathrm{Ce}^{4+}$ salts in a nitrate solution are 8.1 and 2.7 , respectively. ${ }^{16} \mathrm{~A} \mathrm{Ce}^{4+}$ salt, cerium ammonium nitrate, was tested and found to provide usable stable broths. A broth is composed of the cerium salt, HMTA, and urea chilled to 0 to $5^{\circ} \mathrm{C}$. A stable broth is one that remains clear and does not gel or precipitate for reasonable periods $(\geq 1 \mathrm{~h})$ at that temperature.

Before further describing the experimental results, the basic chemical reactions of the internal gelation process must be undersood. ${ }^{5}$ The most important reactions are as follows:

(1) complexation/decomplexation

$$
2 \mathrm{CO}\left(\mathrm{NH}_{2}\right)_{2}+\mathrm{Ce}^{4+} \leftrightarrow \mathrm{Ce}\left[\mathrm{CO}\left(\mathrm{NH}_{2}\right)_{2}\right]_{2}{ }^{4+}
$$

(2) hydrolysis

$$
\begin{aligned}
& \mathrm{Ce}^{4+}+x \mathrm{H}_{2} \mathrm{O} \leftrightarrow \mathrm{Ce}(\mathrm{OH})_{4} \cdot y \mathrm{H}_{2} \mathrm{O}_{9}+4 \mathrm{H}^{+} \text {and } \\
& \mathrm{CeO}^{2+}+x \mathrm{H}_{2} \mathrm{O} \leftrightarrow \mathrm{CeO}(\mathrm{OH})_{2} \cdot y \mathrm{H}_{2} \mathrm{O}_{9}+2 \mathrm{H}^{+}
\end{aligned}
$$


(3) HMTA protonation

$$
\left(\mathrm{CH}_{2}\right)_{6} \mathrm{~N}_{4}+\mathrm{H}^{+} \leftrightarrow\left(\mathrm{CH}_{2}\right)_{6} \mathrm{~N}_{4} \cdot \mathrm{H}^{+}
$$

(4) HMTA decomposition

$$
\left(\mathrm{CH}_{2}\right)_{6} \mathrm{~N}_{4} \cdot \mathrm{H}^{+}+3 \mathrm{H}^{+}+6 \mathrm{H}_{2} \mathrm{O} \leftrightarrow 4 \mathrm{NH}_{4}^{+}+6 \mathrm{CH}_{2} \mathrm{O} .
$$

Urea serves as a complexing agent for the metal (reaction 1). For broths of certain concentrations, the urea allows stable broths to be prepared at temperatures of $0^{\circ} \mathrm{C}$. As the temperature of the broth droplets rises after their injection into the hot organic medium, decomplexation occurs (reaction 1), allowing hydrolysis of the cerium to take place (reaction 2). HMTA, a weak organic base, drives the hydrolysis reaction to completion. At first the HMTA molecules are singularly protonated (reaction 3). Once almost all ( $\geq 95 \%$ ) of the HMTA molecules are protonated, they begin to decompose (reaction 4) into ammonia molecules, a process that makes the system even more basic. Each protonated HMTA molecule can effectively remove three additional hydrogen ions. The reaction products are formaldehyde and ammonium nitrate. In addition to the role of urea as a complexing agent, it also functions as a catalytic agent, which accelerates the decomposition of the protonated HMTA molecules. ${ }^{5}$ 


\section{EXPERIMENTAL RESULTS}

Optimum broth formulations and gel-forming temperatures were determined for making hydrous cerium oxide microspheres via the internal gelation process, which yielded structurally strong gel spheres. One of the most important factors in the formation of the gel spheres is the time needed for broth droplets to gel once they are introduced into the hot immiscible organic medium in the forming column. Ideally gelation should begin in $\leq 10 \mathrm{~s}$.

Stock solutions of $3.18 M$ HMTA and $3.18 M$ urea with a density of $1.14 \mathrm{~g} / \mathrm{mL}$ and $1.675 \mathrm{M}\left(\mathrm{NH}_{4}\right)_{2} \mathrm{Ce}\left(\mathrm{NO}_{3}\right)_{6}$ were used in these experiments. Generally, the rule of thumb is to make a stock solution as concentrated as possible without causing it to be supersaturated at the temperatures of use. Furthermore, when stock solutions can be partially preneutralized, less HMTA and urea are needed to prepare the gel spheres. Separate stock solutions were also prepared in which predetermined volumes of the $\mathrm{Ce}^{4+}$ stock solution were chilled $\left(0\right.$ to $\left.5^{\circ} \mathrm{C}\right)$ and slowly partially neutralized with chilled $14.8 \mathrm{M}$ $\mathrm{NH}_{4} \mathrm{OH}$ and deionized water. Four $1.5 \mathrm{MCe}^{4+}$ stock solutions were prepared with $\mathrm{OH}^{-} / \mathrm{Ce}^{4+}$ mole ratios of $0.00,0.25,0.50$, and 1.00 . Numerous test tube experiments were conducted to determine which broth formulation at $60,70,80$, and $90^{\circ} \mathrm{C}$ had gel times $\leq 10 \mathrm{~s}$ as well as good gel characteristics. The concentrations of $\mathrm{Ce}^{4+}$ in broths with HMTA/ $/ \mathrm{Ce}^{4+}$ mole ratios of $1.5,2.0,2.5,2.75,3.0$, and 3.25 were $0.9,0.77,0.69,0.65$, 0.62 , and $0.59 M$, respectively. The maximum HMTA/ $\mathrm{Ce}^{4+}$ mole ratios for stable broths (i.e., ones that remained clear and did not gel or precipitate for $\geq 1 \mathrm{~h}$ at $0^{\circ} \mathrm{C}$ ) with $\mathrm{OH}^{-} / \mathrm{Ce}^{4+}$ mole ratios of $0.00,0.25,0.50$, and 1.00 , were $3.25,3.25,2.75$, and 2.25, respectively. The results of these tests are given in Figs. 1-8. In Figs. 1-4 gelation time is shown as a function of $\mathrm{HMTA} / \mathrm{Ce}^{4+}$ mole ratio for $\mathrm{Ce}^{4+}$ broths at $90,80,70$, and $60^{\circ} \mathrm{C}$ in which the $\mathrm{OH}^{-} / \mathrm{Ce}^{4+}$ mole ratio is varied from 0.00 to 1.00. In Figs. 5-8 gelation time is shown as function of HMTA $/ \mathrm{Ce}^{4+}$ mole ratio for $\mathrm{Ce}^{4+}$ broths for four different $\mathrm{OH}^{-} / \mathrm{Ce}^{4+}$ mole ratios at constant gel forming temperatures of $60,70,80$, and $90^{\circ} \mathrm{C}$, respectively. Good broth formulations (ones that gelled in $\leq 10 \mathrm{~s}$ ) were determined for each of the preneutralized stock solutions as well as the ones that were not preneutralized. 


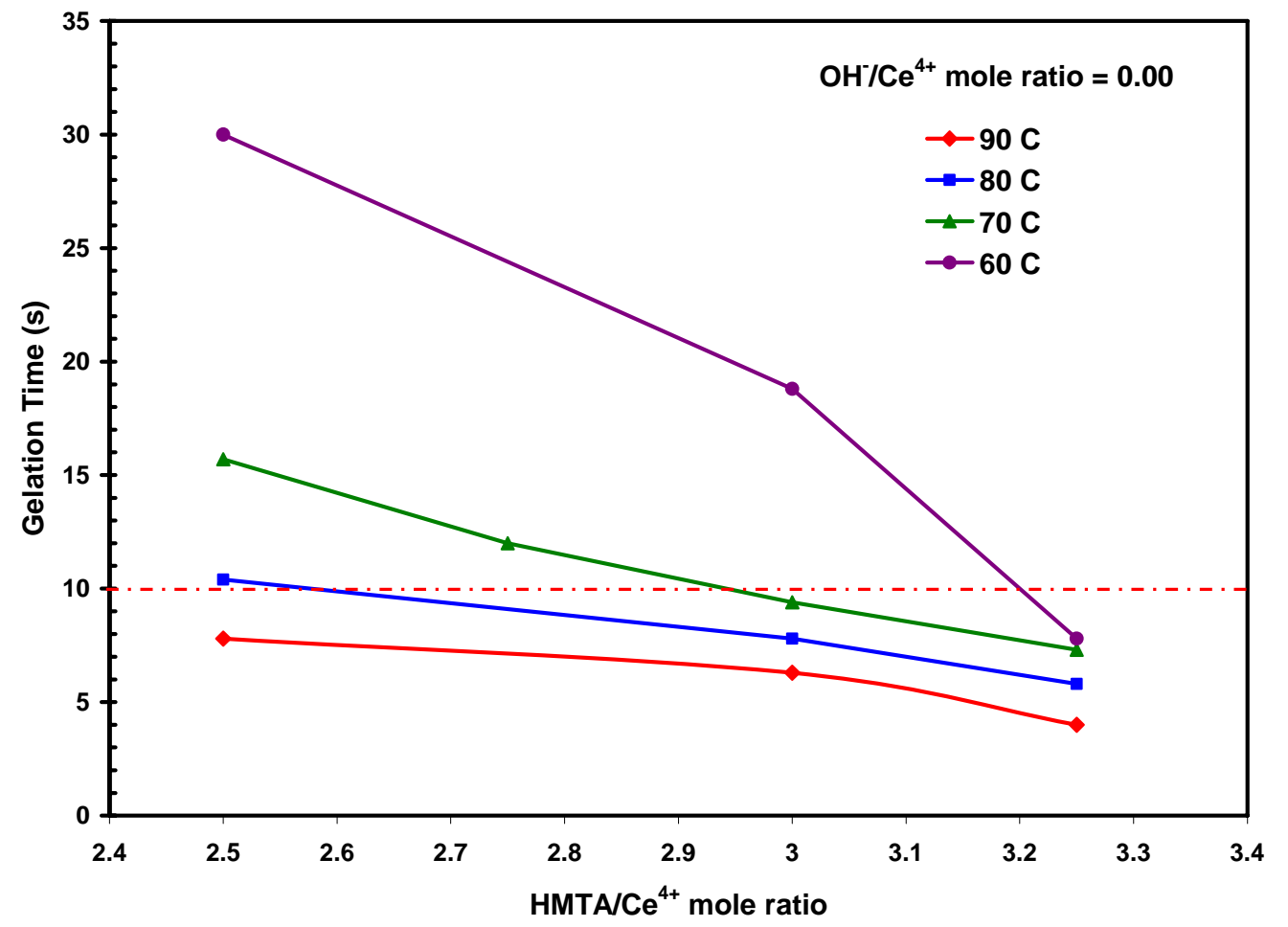

Fig 1. Gelation time as function of $\mathrm{HMTA} / \mathrm{Ce}^{4+}$ mole ratio for $\mathrm{Ce}^{4+}$ broths at 90, 80, 70, and $60^{\circ} \mathrm{C}$ with a $\mathrm{OH}^{-} / \mathrm{Ce}^{4+}$ mole ratio of 0.00 .

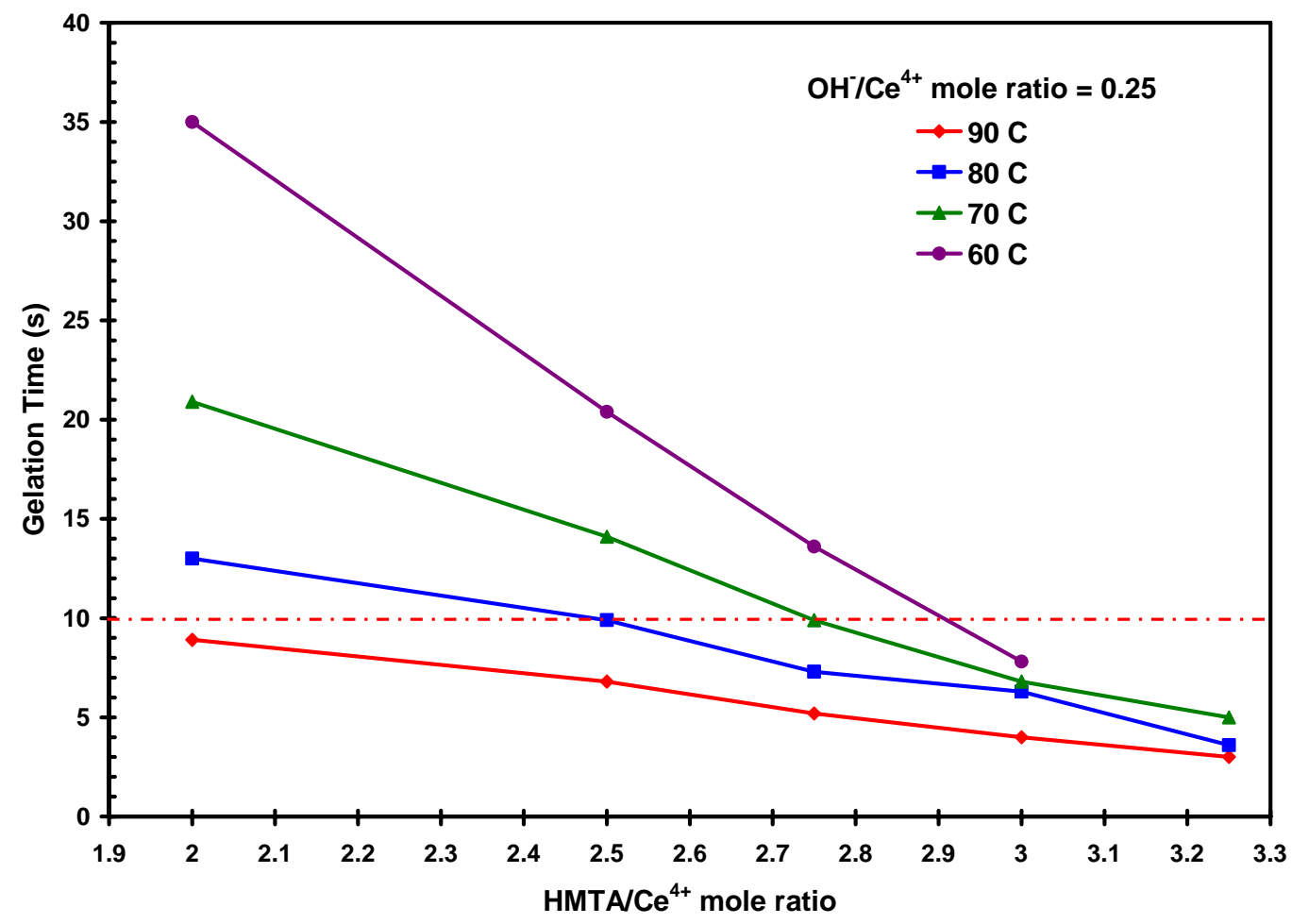

Fig 2. Gelation time as function of $\mathrm{HMTA} / \mathrm{Ce}^{4+}$ mole ratio for $\mathrm{Ce}^{4+}$ broths at $90,80,70$, and $60^{\circ} \mathrm{C}$ with a $\mathrm{OH}^{-} / \mathrm{Ce}^{4+}$ mole ratio of 0.25 . 


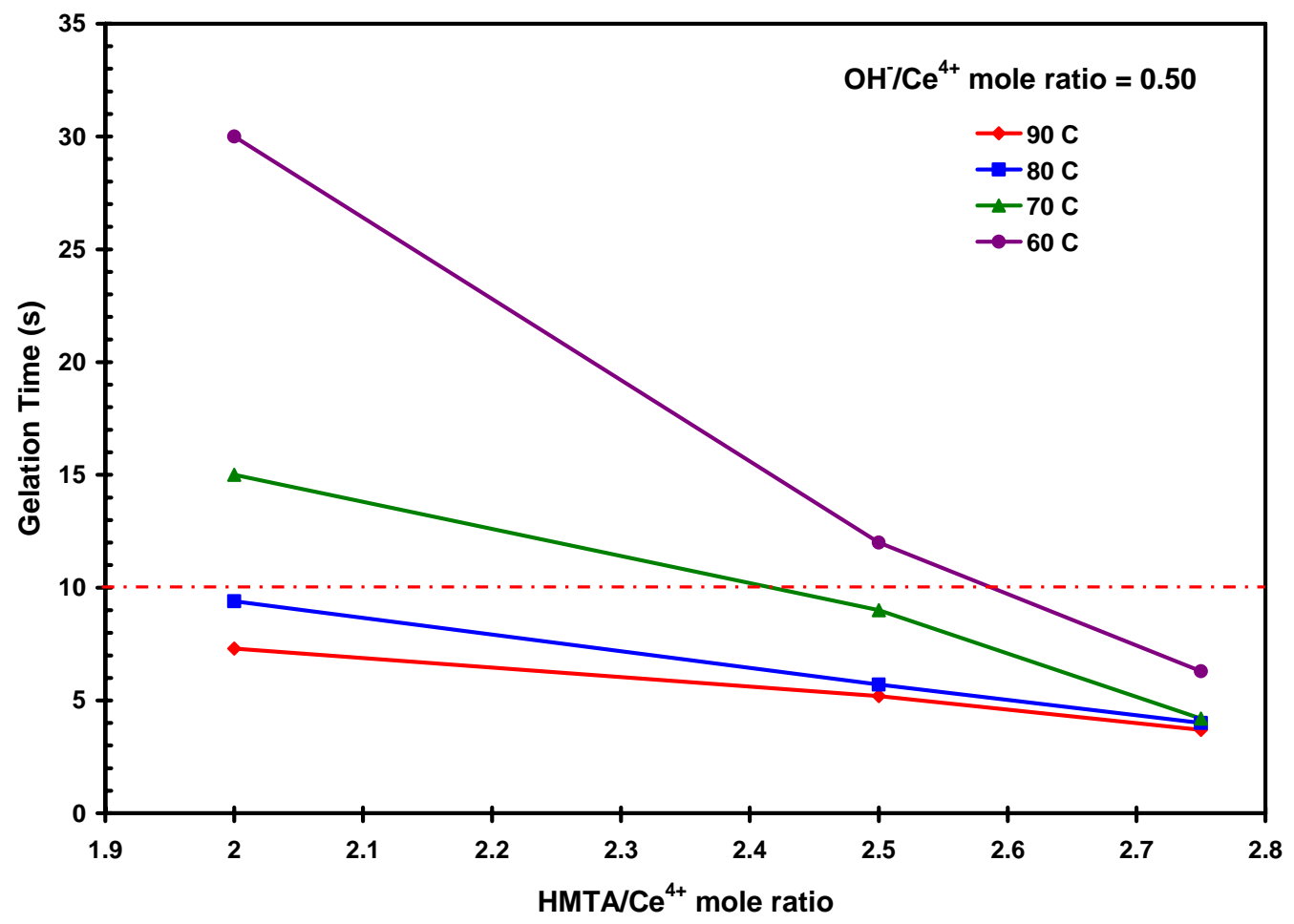

Fig 3. Gelation time as function of $\mathrm{HMTA} / \mathrm{Ce}^{4+}$ mole ratio for $\mathrm{Ce}^{4+}$ broths at $90,80,70$, and $60^{\circ} \mathrm{C}$ with a $\mathrm{OH}^{-} / \mathrm{Ce}^{4+}$ mole ratio of 0.50 .

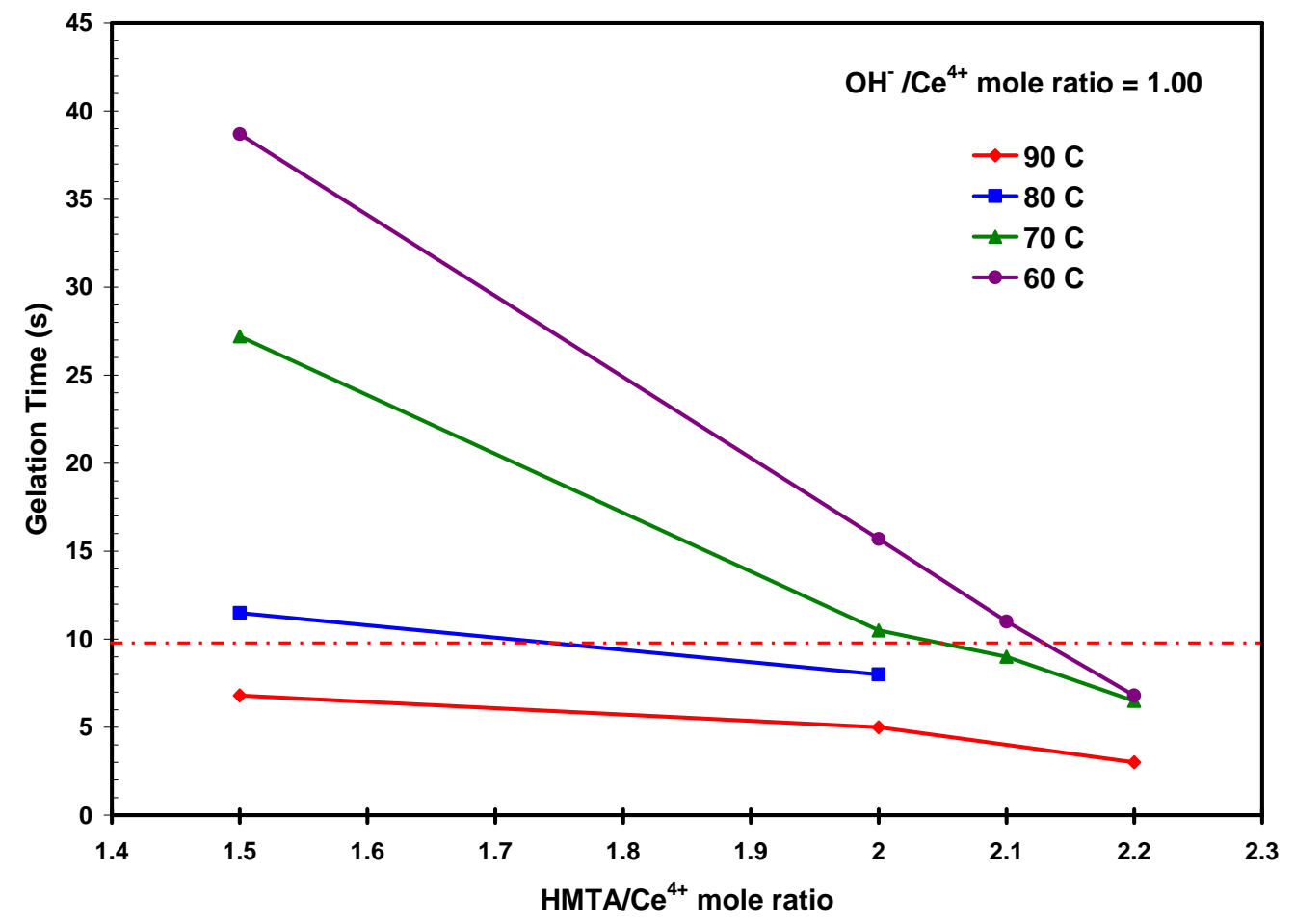

Fig 4. Gelation time as function of $\mathrm{HMTA} / \mathrm{Ce}^{4+}$ mole ratio for $\mathrm{Ce}^{4+}$ broths at $90,80,70$, and $60^{\circ} \mathrm{C}$ with a $\mathrm{OH}^{-} / \mathrm{Ce}^{4+}$ mole ratio of 1.00 . 


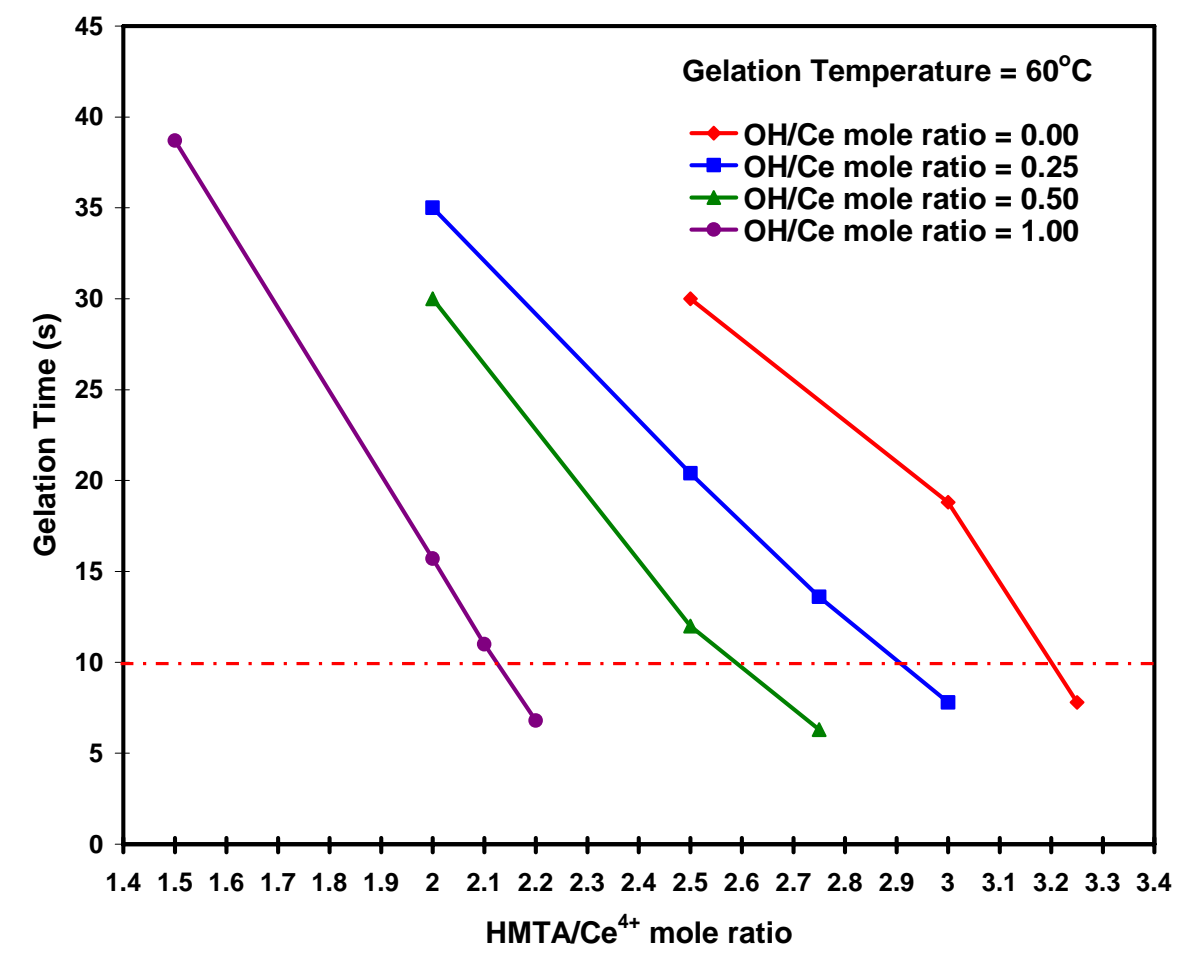

Fig 5. Gelation time as function of $\mathrm{HMTA} / \mathrm{Ce}^{4+}$ mole ratio for $\mathrm{Ce}^{4+}$ broths with four different $\mathrm{OH}^{-} / \mathrm{Ce}^{4+}$ mole ratios at a gel-forming temperature of $60^{\circ} \mathrm{C}$.

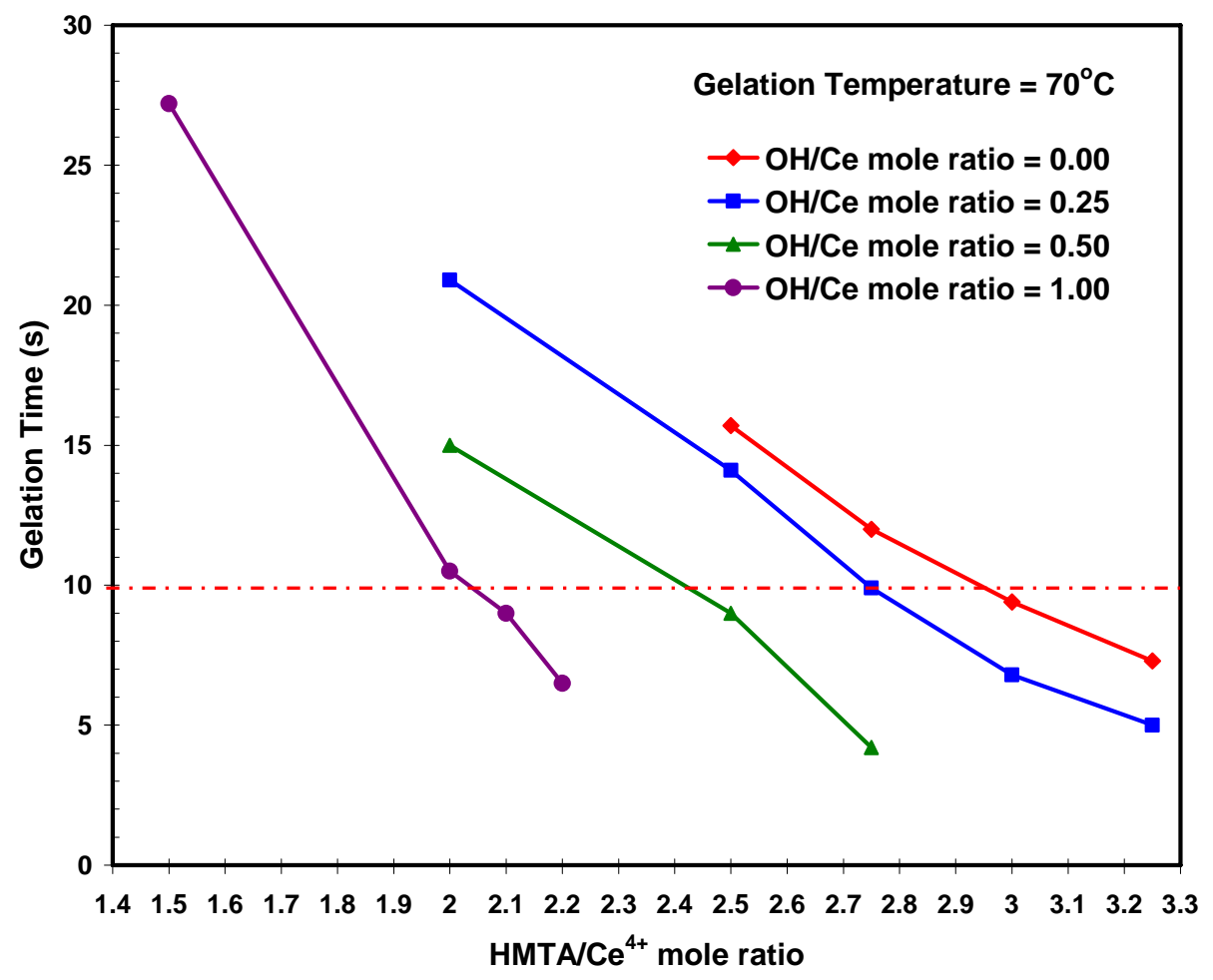

Fig 6. Gelation time as function of $\mathrm{HMTA} / \mathrm{Ce}^{4+}$ mole ratio for $\mathrm{Ce}^{4+}$ broths with four different $\mathrm{OH}^{-} / \mathrm{Ce}^{4+}$ mole ratios at a gel-forming temperature of $70^{\circ} \mathrm{C}$. 


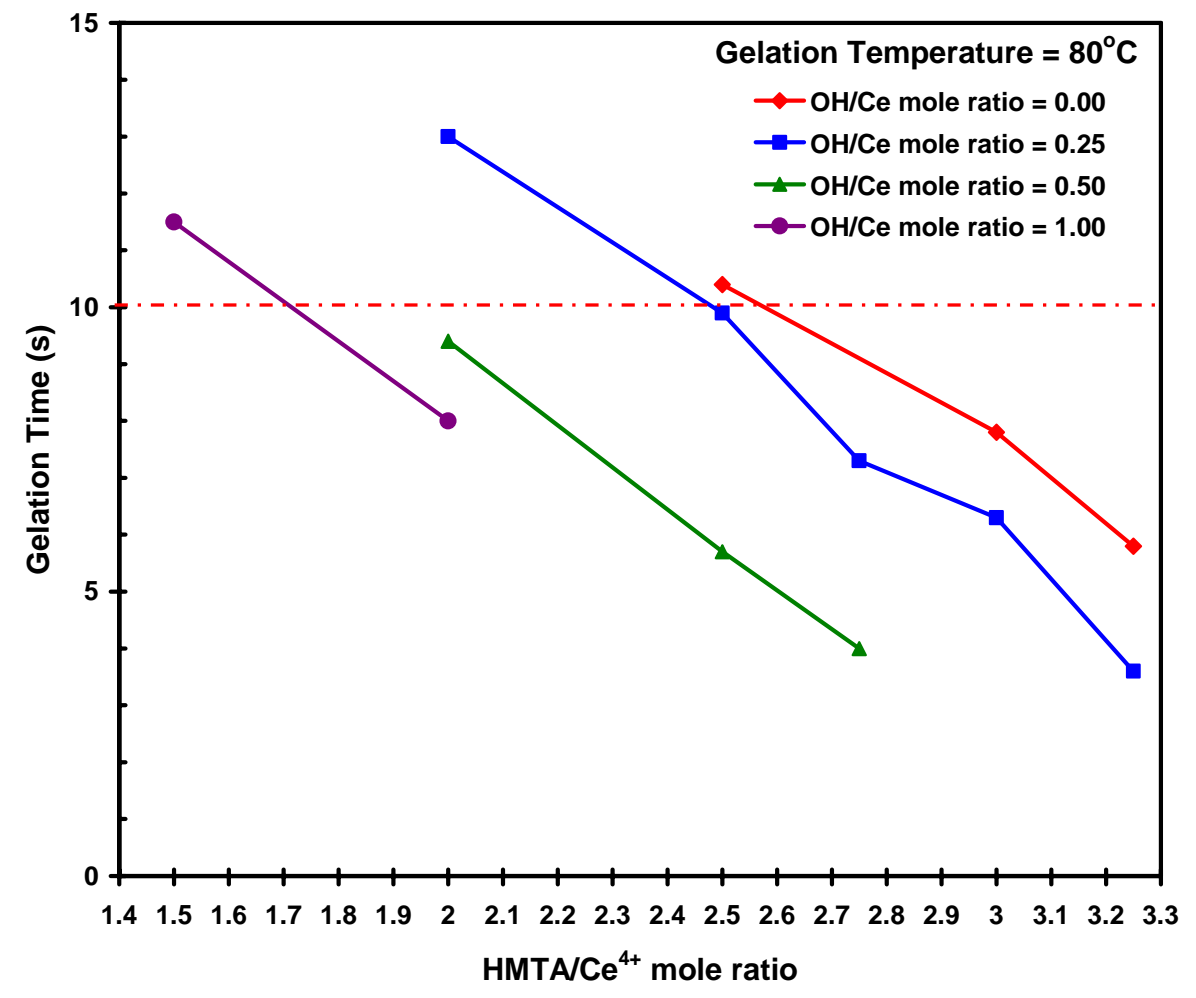

Fig 7. Gelation time as function of $\mathrm{HMTA} / \mathrm{Ce}^{4+}$ mole ratio for $\mathrm{Ce}^{4+}$ broths with four different $\mathrm{OH}^{-} / \mathrm{Ce}^{4+}$ mole ratios at a gel-forming temperature of $80^{\circ} \mathrm{C}$.

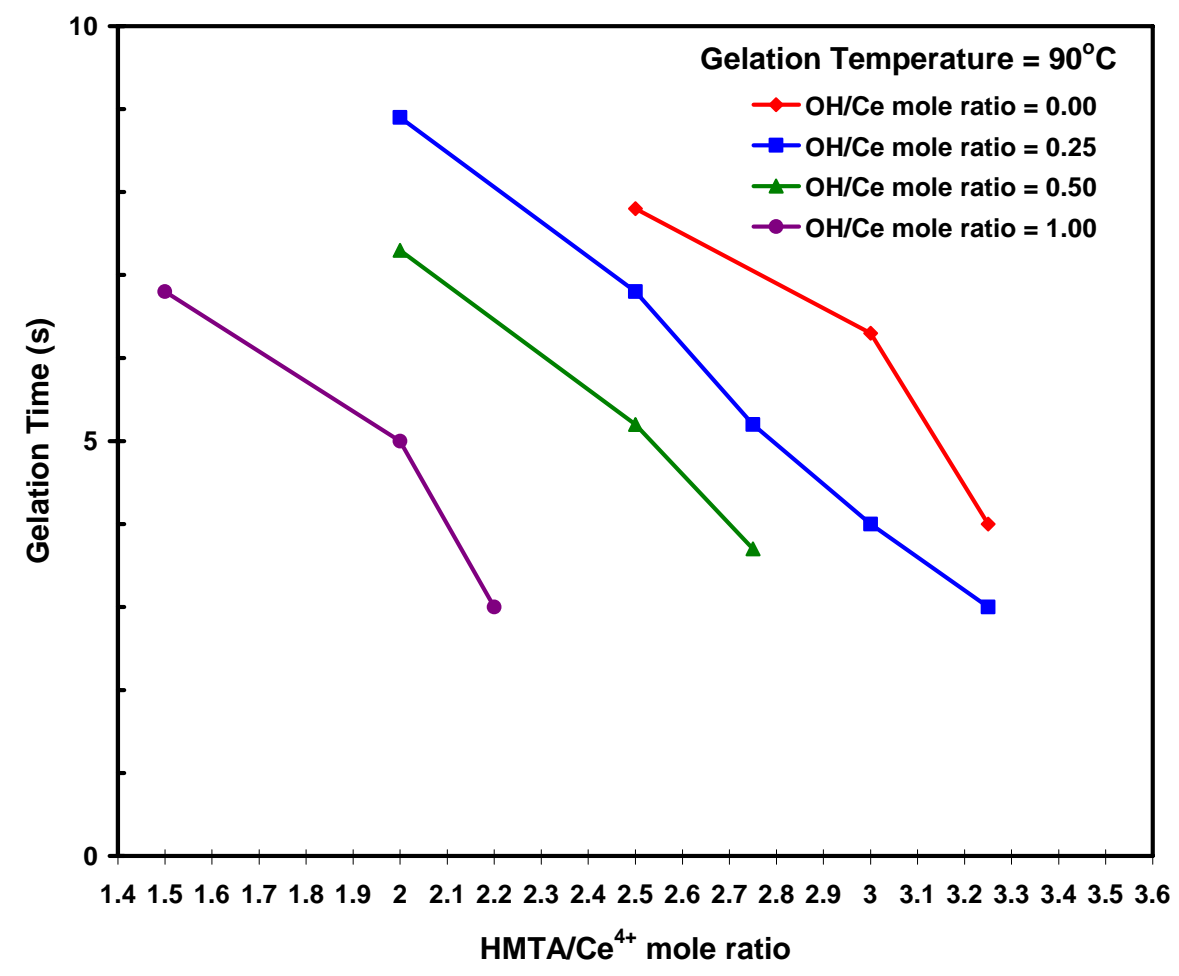

Fig 8. Gelation time as function of $\mathrm{HMTA} / \mathrm{Ce}^{4+}$ mole ratio for $\mathrm{Ce}^{4+}$ broths with four different $\mathrm{OH}^{-} / \mathrm{Ce}^{4+}$ mole ratios at a gel-forming temperature of $90^{\circ} \mathrm{C}$. 
Based upon the exploratory testing in this study, Table 1 gives the best broth formulations for making hydrous cerium oxide gel spheres at $90,80,70$, and $60^{\circ} \mathrm{C}$. If silicone oil is used as the immiscible gel-forming media, any of these formulations can be used. If trichloroethylene (TCE) is used, then the best broth formulation given for the gel-forming temperatures of 60 or $70^{\circ} \mathrm{C}$ should be used. Aging at higher temperatures tended to cause the gel spheres to crack. However, all formulations at each of the indicated temperatures should produce good microspheres. All gel times for these formulations were $<10 \mathrm{~s}$ and produced gel spheres of firm structure. This study also revealed that the best gel spheres are ones that are aged for $15-20 \mathrm{~min}$ at $60-70^{\circ} \mathrm{C}$. The HMTA/ $/ \mathrm{e}^{4+}$ mole ratio needed for usable broth formulas decreased from 3.25 to 1.67 as the $\mathrm{OH}^{-} / \mathrm{Ce}^{4+}$ mole ratio was increased from 0.00 to 1.00 . Gel spheres from good formulations which were aged at 60 or $70^{\circ} \mathrm{C}$ were pale yellow in color and were semitranslucent. Gel spheres aged at higher temperatures were more brownish in color and again tended to be cracked. Aged gels with lower pHs $(<4)$ with gelation times $>10 \mathrm{~s}$ were not completely gelled. In the test-tube experiments, the gels were aged for $10 \mathrm{~min}$ and then cooled to ambient temperature, and the rigidity and $\mathrm{pH}$ of these gels were subsequently measured, as described in Appendix B. The $\mathrm{pH}$ of the aged gels were generally $>4.9$, with most in the range of 5.2 to 5.5 , indicating the completeness of gelation. The rigidity values for each of the broths tested ranged from 1 to 6 on a scale of 1 to 10 , with 1 being very fluid-like water and 10 being very hard. Usable gels that formed in $\leq 10 \mathrm{~s}$ at each of the four temperatures were in the range of 4 to 5 . Broths with $\mathrm{HMTA} / \mathrm{Ce}^{4+}$ mole ratios of $\leq 1.5$ had rigidities of 1 and were not gelled. 
Table 1. Recommended broth formulations as a function of temperature of preparing hydrous cerium oxide gel spheres via the internal gelation process

\begin{tabular}{|c|c|c|c|c|c|}
\hline $\begin{array}{l}\text { Temp. } \\
\left({ }^{\circ} \mathrm{C}\right)\end{array}$ & $\begin{array}{c}\mathrm{OH}^{-} / \mathrm{Ce}^{4+} \\
\text { (mole ratio) }\end{array}$ & $\begin{array}{l}\text { HMTA/Ce }{ }^{4+} \\
\text { (mole ratio) }\end{array}$ & $\begin{array}{c}\mathrm{Ce}^{4+} \text { Broth } \\
\text { Concentration } \\
(M)\end{array}$ & $\begin{array}{l}\text { Gelation } \\
\text { Time } \\
\text { (s) }\end{array}$ & $\begin{array}{c}\text { Rigidity } \\
\text { Scale of } \\
1-10^{a}\end{array}$ \\
\hline 90 & 0.00 & 2.50 & 0.69 & 8 & 4 \\
\hline 80 & 0.00 & 3.00 & 0.62 & 8 & 4 \\
\hline 70 & 0.00 & 3.25 & 0.59 & 7 & 4 \\
\hline 60 & 0.00 & 3.25 & 0.59 & 8 & 4 \\
\hline 90 & 0.25 & 2.75 & 0.65 & 5 & 4 \\
\hline 80 & 0.25 & 2.75 & 0.65 & 7 & 5 \\
\hline 70 & 0.25 & 3.00 & 0.62 & 7 & 5 \\
\hline 60 & 0.25 & 3.00 & 0.62 & 8 & 5 \\
\hline 90 & 0.50 & 2.50 & 0.69 & 5 & 4 \\
\hline 80 & 0.50 & 2.50 & 0.69 & 6 & 4 \\
\hline 70 & 0.50 & 2.75 & 0.65 & 5 & 4 \\
\hline 60 & 0.50 & 2.75 & 0.65 & 6 & 4 \\
\hline 90 & 1.00 & 2.00 & 0.77 & 5 & 4 \\
\hline 80 & 1.00 & 2.00 & 0.77 & 8 & 4 \\
\hline 70 & 1.00 & 2.20 & 0.74 & 6 & 4 \\
\hline 60 & 1.00 & 2.20 & 0.74 & 7 & 4 \\
\hline
\end{tabular}

${ }^{a}$ Very good gel characteristics: completely gelled with rigidity values of $4-5$. The color of all these gels was semitranslucent yellow. 


\section{EXAMPLE OF ONE OF THE LAB-SCALE HYDROUS CERIUM OXIDE MICROSPHERE PREPARATIONS}

A $163.6-\mathrm{mL}$ broth was prepared by slowly mixing $88.6 \mathrm{~mL}$ of chilled $3.18 \mathrm{M}$ HMTA and $3.18 \mathrm{M}$ urea solution ( $\left(0\right.$ to $5^{\circ} \mathrm{C}$ ) with $75 \mathrm{~mL}$ of chilled $1.5 \mathrm{M}$ cerium stock solution prepared with a $\mathrm{OH}^{-} / \mathrm{Ce}^{+4}$ mole ratio of 0.50 . The $\mathrm{HMTA} / \mathrm{Ce}^{+4}$ and urea $/ \mathrm{Ce}^{+4}$ mole ratios were 2.5. The color of the cerium solution turned from orange to yellow upon the addition of the HMTA-urea solution. The concentrations of $\mathrm{Ce}^{+4}$, HMTA, and urea for the broth were $0.69,1.72$, and $1.72 \mathrm{M}$, respectively. A two-fluid nozzle system with a 21-gauge flat-tipped needle was used to expel the broth droplets. ${ }^{10}$ From the tip of the needle, the broth droplets were introduced into a flowing stream of heated immiscible organic medium $\left(\sim 70^{\circ} \mathrm{C}\right)$. Silicone oil (Dow Corning 200 silicone fluid) was used in this preparation. The droplets were then transported into the gel-forming apparatus. The size of the droplets could be controlled by using the two-fluid nozzle system and by varying the gauge of the needle and the flow rates of the hot silicone oil and the chilled broth. The droplets began to gel in about $9 \mathrm{~s}$ and were subsequently collected in a stainless steel mesh basket downstream. It took $\sim 30 \mathrm{~s}$ for the gelled microspheres to reach the basket. The run lasted $\sim 53 \mathrm{~min}$. Afterward, the microspheres were aged for $20 \mathrm{~min}$ in silicone oil at $\sim 70^{\circ} \mathrm{C}$ to complete the gelation process, then washed six times with TCE to remove the silicone oil, and then washed six times with $0.5 \mathrm{M} \mathrm{NH}_{4} \mathrm{OH}$ to remove the reaction impurities. The bead volume after the washing steps was $\sim 72 \mathrm{~mL}$. The microspheres were then air dried at ambient temperature. About $29.8 \mathrm{~g}$ of microspheres were obtained from this run. The measured tap density was $1.9 \mathrm{~g} / \mathrm{ml}$. The run was a success, and the gel time was the same as that predicted by the test tube experiments.

\section{ACKNOWLEDGMENTS}

The author appreciates the support of Ben Lewis and the managerial and financial support that allowed this report to be written; Rodney Hunt and Barry Spencer for their technical reviews; Marsha Savage for editing services; and Brenda Johnson for preparation of the document. 


\section{REFERENCES}

1. J. L. Collins, Experimental Methodology for Determining Optimum Process Parameters for Production of Hydrous Metal Oxides by Internal Gelation, ORNL/TM-2005/102, June 2005.

2. F. W. van der Brugghens, A. J. Noothout, M. E. A. Hermans, J. B. W. Kanij, and O. Votocek, "A U(VI)-Process for Microsphere Production," in Proc. Symp. Sol-Gel Processes and Reactor Fuel Cycles, Gatlinburg, Tennessee, May 4-7, 1970, CONF700502, U.S. Atomic Energy Commission, 1970.

3. P. A. Haas, J. M. Begovich, A. D. Ryon, and S. J. Vavruska, Chemical Flowsheet for Preparing Urania Spheres by Internal Gelation, ORNL/TM-6850, Oak Ridge National Laboratory, Oak Ridge, Tenn., July 1979.

4. M. H. Lloyd, J. L. Collins, R. L. Fellows, S. E. Shell, D. H. Newman, and W. B. Stines, A Gel Sphere Process for FBR Fuel Fabrication from Coprocessed Feed, ORNL/TM-8399, Oak Ridge National Laboratory, Oak Ridge, Tenn., February 1983.

5. J. L. Collins, M. F. Lloyd, and R. L. Fellows, "The Basic Chemistry Involved in the Internal-Gelation Method of Precipitating Uranium as Determined by $\mathrm{pH}$ Measurements," Radiochim. Acta 42, 121-34 (1987).

6. Milton H. Lloyd, Jack L. Collins, and Sam E. Shell, "Method of Controlling Crystallite Size in Nuclear-Reactor Fuels," U.S. Patent No. 4,502,987, March 5, 1985.

7. J. L. Collins, R. D. Hunt, G. D. Del Cul, and D. F. Williams, Production of Depleted $\mathrm{UO}_{2}$ Kernels for the Advanced Gas-Cooled Reactor Program for Use in TRISO Coating Development, ORNL/TM-2004/123, December 2004.

8. J. L. Collins, "Method of Preparing Hydrous Zirconium Oxide Gels and Spherules," U.S. Patent No. 6,602,919 B1, Aug. 5, 2003.

9. J. L. Collins, "Method of Preparing Hydrous Titanium Oxide Gels and Spherules," U.S. Patent No. 5,821,186, Oct. 13, 1998.

10. J. L. Collins, R. J. Lauf, and K. K. Anderson, "Method of Preparing Hydrous Iron Oxide Gels and Spherules," U.S. Patent No. 6,599,493 B2, July 29, 2003.

11. J. L. Collins and K. K. Anderson, Development of Spheroidal Inorganic Sorbents for Treatment of Acidic Salt-bearing Liquid Waste, ORNL/TM-2000/367, September 2001.

12. J. L. Collins and J. S. Watson, Economic Evaluation for the Production of Sorbents and Catalysts Derived from Hydrous Titanium Oxide Microspheres Prepared by the HMTA Internal Gelation Process, ORNL/TM-1999/212, April 2000. 
13. R. J. Lauf, K. K. Anderson, F. C. Montgomery, J. L. Collins, and J. J. Felton, "Method for Preparing Dielectrics Composite Materials Use Thereof," U.S. Patent No. 2004/6,821,474, Nov. 23, 2004.

14. R. J. Lauf, K. K. Anderson, F. C. Montgomery, J. L. Collins, and J. J. Feldon, "Method of Preparing Spherical Ferrite Beads and Use Thereof," U.S. Patent No. 2003/0129387 A1, July 10, 2003.

15. R. J. Lauf, K. K. Anderson, F. C. Montgomery, and J. L. Collins, "Method of Preparing Spherical Ferrite Beads and Use Thereof," U.S. Patent No. 6,492,016 B1, Dec. 10, 2002.

16. P. C. Stevenson and W. E. Nervik, The Radiochemistry of the Rare Earths, Scandium, Yttrium, and Actinium, National Academy of Sciences National Research Council Nuclear Series, NAS-NS 3020, February 1961. 


\section{APPENDIX A \\ BROTH STABILITY TESTS}

A stable broth is one that remains clear and does not gel or precipitate for a reasonable period of time at $\sim 0^{\circ} \mathrm{C}$ (usually about $1 \mathrm{~h}$ ). A $1.675 \mathrm{M}$ cerium ammonium nitrate $\left.\left[\left(\mathrm{NH}_{4}\right)_{2} \mathrm{Ce}\left(\mathrm{NO}_{3}\right)_{6}\right)\right]$ stock solution was prepared and analyzed for accuracy by gravimetric analysis (see Appendix C). Separate stock solutions were also prepared in which predetermined volumes of the $\mathrm{Ce}^{4+}$ stock solution were chilled $\left(0\right.$ to $\left.5^{\circ} \mathrm{C}\right)$ and slowly partially neutralized with chilled $14.8 \mathrm{M} \mathrm{NH}_{4} \mathrm{OH}$ and deionized water. Six $1.5 \mathrm{M}$

$\mathrm{Ce}^{4+}$ stock solutions were prepared with $\mathrm{OH}^{-} / \mathrm{Ce}^{4+}$ mole ratios of $0.00,0.25,0.50,1.00$, and 1.50. Calculated amounts of chilled HMTA/urea, stock solution, and water were mixed together to produce each broth. The stability test procedure was as follows.

1. A rack for holding thin-walled glass centrifuge tubes was placed in an ice bath. Predetermined volumes of 3.18 M HMTA/3.18 M urea and stock solutions were separately and carefully pipetted into these tubes via calibrated electronic pipettes, and the tubes were subsequently chilled for $\sim 20 \mathrm{~min}$. The centrifuge tubes containing the cerium stock solutions also served as the broth tubes and were labeled accordingly as to stock solution that was used and the HMTA/Ce ${ }^{4+}$ and $\mathrm{OH}^{-} / \mathrm{Ce}^{4+}$ mole ratios.

2. To prepare a broth, a predetermined volume of chilled HMTA/urea was carefully removed with a pipette and transferred to a centrifuge tube containing a predetermined volume of cerium stock solutions. Because of the small volumes involved, it was important that the transfer was quantitative. The broth was then mixed well with a Teflon stirring rod. The time of mixing was recorded, and the broth was observed until the first visual sign of gelation, or for $1 \mathrm{~h}$. The time of gelation was recorded. Tests were performed in duplicate. 



\section{APPENDIX B \\ GEL TESTS IN GLASS CENTRIFUGE TUBES}

\section{Apparatus}

The apparatus used for the gel tests was simple and consisted of the following components:

- 2-L beaker containing ice water

- 4-L beaker containing heated water

- hot plate with stirring capability

- dial thermometer

- calibrated Metler DE 200 analytical balance (0- to 200-g range with a readability of $0.0001 \mathrm{~g})$

- calibrated continuously adjustable digital pipette (100- to $1000-\mu \mathrm{L}$ range) or a calibrated Rainin EDP-Plus electronic pipette with interchangeable liquid ends that cover the 100 - to $1000-\mu \mathrm{L}$ and 250 - to $2500-\mu \mathrm{L}$ ranges, plus concomitant disposable tips

- ROSS $^{\text {TM }}$ Sure-Flow combination $\mathrm{pH}$ electrode, which provides temperature compensation for temperatures in the 0 to $100^{\circ} \mathrm{C}$ range

- in-date standard $\mathrm{pH} 7$ and $\mathrm{pH} 4$ buffer solutions

- 12-mL glass centrifuge tubes

- 8-in.-long Teflon-coated microspatulas

\section{Testing Procedure}

The gel test procedure was as follows.

1. A portion of the cerium feed solution (at room temperature) and deionized water was carefully pipetted into the bottom of a glass centrifuge tube in an ice bath. The required volume of HMTA/urea was pipetted into the bottom of a separate plastic centrifuge tube in an ice bath. Both were chilled for $10 \mathrm{~min}$ to attain ice bath temperature. The chilled HMTA/urea was then quantitatively pipetted into the chilled cerium solution and well mixed. Care was taken not to splash the broth onto the test tube walls. The broth was maintained in the ice bath for an additional $5 \mathrm{~min}$. 
2. The broth tube was then placed in a hot water bath at the desired temperature. The test tube was gently swirled in the water bath to observe when the gel set. A stopwatch was used to measure the time in the bath needed for gelation to occur. As gelation began, the clear broth became viscous and motionless. The gel was then allowed to age for $10 \mathrm{~min}$ in the hot bath at 70 or $60^{\circ} \mathrm{C}$.

3. The test tube was then removed from the hot bath, and the gel was allowed to cool to room temperature. The transparency of the gel [on a scale of 1 (transparent) to 10 (opaque)] was subjectively determined and recorded. The rigidity of the gel was subjectively determined by inserting a spatula into the center of the gel and was quantified on a subjective scale of 1 (no resistance, almost like water) to 10 (high resistance, difficult to penetrate).

4. The gel was then broken up by stirring with the spatula. Afterward, the test tube was centrifuged to remove pockets of air and to compact the gel into the bottom of the tube. A calibrated $\mathrm{pH}$ probe was inserted into the gel to measure the $\mathrm{pH}$. It took up to $30 \mathrm{~s}$ for the $\mathrm{pH}$ reading to stabilize.

At a minimum, duplicates of each broth were tested to ensure accuracy. If the gel times and properties matched, the test results were assumed to be acceptable. If the gel times did not match, additional tests were conducted to resolve the problem and obtain consistent values. 


\section{APPENDIX C GRAVIMETRIC ANALYSIS PROCEDURE}

The following gravimetric analysis procedure was used to determine the concentration of cerium ammonium nitrate $\left[\left(\mathrm{NH}_{4}\right)_{2} \mathrm{Ce}\left(\mathrm{NO}_{3}\right)_{6}\right]$ in stock solution:

- Heated a small ceramic crucible and covered it at $800^{\circ} \mathrm{C}$ in a muffle furnace for $1 \mathrm{~h}$ in air atmosphere.

- $\quad$ Turned off the furnace, cooled to about $200^{\circ} \mathrm{C}$, and removed the crucible and the cover from the furnace. Placed them in a desiccator and finished cooling to ambient temperature.

- Removed the crucible and cover from desiccator and immediately weighed them. All weights were taken to the nearest $0.0001 \mathrm{~g}$.

- Using a calibrated pipette, carefully added $2 \mathrm{~mL}$ of a cerium ammonium nitrate solution to the crucible.

- Heated the covered crucible with solution under a heat lamp until almost all the water had evaporated. This reduced the chance of splattering and loss of the analyte.

- $\quad$ Placed sample in furnace and slowly heated to $900^{\circ} \mathrm{C}$ and held at that temperature for $2 \mathrm{~h}$.

- $\quad$ Turned the furnace off and cooled to $\sim 200^{\circ} \mathrm{C}$. Removed the sample from furnace, placed it in a desiccator, and cooled to ambient temperature.

- Removed the sample from desiccator and immediately weighed it. All weights were taken to the nearest $0.0001 \mathrm{~g}$.

- By subtracting the tarred weight of the crucible and lid, the weight of $\mathrm{CeO}_{2}(\mathrm{FW}=$ $172.12 \mathrm{~g} / \mathrm{mole}$ ) was determined.

- To confirm the identity, a sample was taken and analyzed by X-ray diffraction to prove it was pure $\mathrm{CeO}_{2}$.

\section{$\underline{\text { Analytical Results }}$}

An automatic pipette was calibrated by setting it to $1000 \mu \mathrm{L}$ and delivering that amount to a tared beaker and weighing it. This was done ten times, and the results were $1.0025,0.9989,0.9987,1.0022,1.0000,1.0079,1.0032,1.0022,1.0020$, and $1.0007 \mathrm{~g}$. The average value was $1.0018 \mathrm{~g}$, meaning that the pipette was delivering an average of $1.0018 \mathrm{~mL}$. 
Analyses of three 2-mL samples of stock solution were performed as describe in the procedure. X-ray analysis of a sample from sample no. 1 confirmed that the product was $\mathrm{CeO}_{2}$ and the average concentration for the three samples was $1.675 \mathrm{M} \mathrm{Ce}^{4+}$.

\begin{tabular}{cccc}
\hline $\begin{array}{c}\text { Sample } \\
\text { No. }\end{array}$ & $\begin{array}{c}\mathrm{CeO}_{2} \text { obtained } \\
\text { (g) }\end{array}$ & $\begin{array}{c}\mathrm{CeO}_{2} \text { obtained } \\
\text { (mole) }\end{array}$ & $\begin{array}{c}\mathrm{Ce}^{4+} \text { concentration } \\
\text { (mole/L) }\end{array}$ \\
\hline 1 & 0.5776 & 0.003356 & $1.675^{a}$ \\
2 & 0.5778 & 0.003357 & 1.675 \\
3 & 0.5762 & 0.003359 & 1.676 \\
& & Average & $\mathbf{1 . 6 7 5}$
\end{tabular}

${ }^{a}\left[(0.003356 \mathrm{~mole})\left(10^{-3}\right] /\left[(1.0018 \mathrm{~mL})(2)\left(10^{-3} \mathrm{ml} / \mathrm{L}\right)\right]=1.675 \mathrm{~mole} / \mathrm{L}\right.$. 